\title{
BACTERIAL STRAINS DECREASE SOLUBILITY OF POTASSIUM IN THE SOIL
}

\author{
ESTIRPES BACTERIANAS REDUZEM POTENCIAL DE SOLUBILIZAÇÃO DE \\ POTÁSSIO NO SOLO
}

\section{Mário Viana PAREDES FILHO ${ }^{1}$; Aline Carvalho MESQUITA ${ }^{1}$; José Ricardo MANTOVANI ${ }^{\mathbf{1}}$; Adauton Vilela de REZENDE ${ }^{1}$; Ligiane Aparecida FLORENTINO ${ }^{1}$ \\ 1. Universidade José do Rosário Vellano, Departamento de Agronomia, Alfenas, MG, Brasil. mariomecanica@outlook.com.}

\begin{abstract}
This study aimed to verify whether inoculation with strains of diazotrophic bacteria, with proven ability to solubilize potassium $(\mathrm{K})$ in vitro, contributes towards the release of $\mathrm{K}$ in the soil after fertilization with phonolite rock powder. The experiment was conducted in containers with $0.3 \mathrm{dm}^{-3}$ of soil containing low potassium content. Fifteen treatments were used, namely, 12 inoculated with the bacterial strains, a control treatment (without phonolite and without inoculation), one containing phonolite without inoculation and one containing $\mathrm{KCl}$, soluble fertilizer, without inoculation. In treatments with phonolite and $\mathrm{KCl}$, the doses of these materials were applied to provide the soil with $195 \mathrm{mg} \mathrm{dm}^{-3}$ of $\mathrm{K}$. A completely randomized design with four replications was used. The soil was incubated during 90 days at room temperature and humidity at about $70 \%$ retention capacity. After this period, the content of $\mathrm{K}^{+}$(Mehlich and resin), $\mathrm{pH}$ value and potential acidity $(\mathrm{H}+\mathrm{Al})$ were evaluated. Phonolite, associated with inoculation with most bacterial strains, increased the availability of potassium in the soil, $\mathrm{pH}$ rate and reduced potential acidity. Among the strains tested, UNIFENAS 100-01, UNIFENAS 100-16, UNIFENAS 100-27, UNIFENAS 100-39 and UNIFENAS 100-93 were the most efficient for the solubilization of $\mathrm{K}^{+}$of the phonolite. In spite of the observed results, $\mathrm{K}$ content released by the bacterial strains in the soil decreased when compared to in vitro conditions, thus justifying the need for studies on bio-solubilization of soil to select the most efficient strains in the process.
\end{abstract} solubilization.

KEYWORDS: Alternative sources of potassium. Silicate rock powder. Limiting factors of bio-

\section{INTRODUCTION}

The bio-solubilization of nutrients, such as potassium, in rock minerals, performed by several soil microorganism groups has been studied over and over again due to their capacity for partial or total replacement of imported soluble potassium fertilizers by those found in Brazil. Potassium (K) ranks second as the most absorbed macronutrient by plants (MALAVOLTA, 2006). Its functions within the vegetal metabolism are related to photosynthetic capacity, translocation of carbohydrates, cell osmosis regulation, enzyme co-factor and a greater efficiency in nitrogen fertilization (ANDRADE et al., 2000; MALAVOLTA, 2006; FILGUEIRA, 2008). Lack or deficiency of $K$ in the soil limits the development of plants and their productivity.

Since soils in Brazil normally have low $\mathrm{K}^{+}$ rates, high doses of the nutrient are frequently applied through mineral fertilizers. More than 90\% of potassium fertilizers used in agriculture in Brazil are imported from Canada, Germany and Byelorussia (DNPM, 2014). Needless to say, high dependence on foreign market increases costs and triggers studies on alternative sources of the nutrient (MARTINS et al., 2015b).

Powder from silicate rocks found in Brazil, such as verdetes, gneisses, granites and phonolites, may be an alternative source for potassium fertilizers (TEIXEIRA et al., 2012; MANCUSO et al., 2014; SANTOS et al., 2015). The solubility of the powder of the above minerals is low and the release of potassium is slow and gradual, with decrease in losses by leaching and soil salinity. It actually provides long term activity (MANCUSO et al., 2014; MARTINS et al., 2015b). On the other hand, slow $\mathrm{K}$ release is not a positive characteristic from the nutritional point of view since nutrient absorption by plants is impaired. Deficiency may occur and the development and production of plants may be affected (BRANDÃO; LOPES-ASSAD; CECCATO-ANTONINI, 2014).

The use of physical-chemical treatments, such as high temperature and the addition of $\mathrm{NH}_{4} \mathrm{OH}$ (MARTINS et al., 2015a), triggers the release of nutrients in the rocks. Costs are high and 
consumption may become unfeasible. A low-cost and sustainable form, without the generation of possible environmental damages, is the use of $\mathrm{K}$ solubilizing microorganisms which increase the availability of $\mathrm{K}$ of silicate rocks by the release of organic acids (GIRGIS; KHALIL; SHARAF, 2008; BRANDÃO; LOPES-ASSAD; CECCATOANTONINI, 2014; MEENA; MAURYA; VERMA, 2014; FLORENTINO et al., 2017).

However, most research works above have been developed in in vitro conditions and require evaluations with the microorganisms behavior in the soil. The above is highly relevant due to the fact that other groups of microorganisms and different edaphoclimatic conditions may interfere in the survival and efficiency of $K$ solubilizing microorganisms in the soil (MEENA; MAURYA; VERMA, 2014).

This study aimed to verify whether inoculation by diazotrophic bacteria strains of proven capacity for in vitro solubilization of $\mathrm{K}$ contribute towards the release of potassium in the soil after fertilization by phonolite powder.

\section{CONTENTS}

Twelve strains of diazotrophic bacteria of proven capacity in $\mathrm{K}$ solubilization from phonolite rocks when cultivated in a culture medium were employed (FLORENTINO et al., 2017). Table 1 shows the main morphological characteristics of bacterial strains used in current analysis.

Table 1. Identification, isolation site, concentration of potassium in soils, medium used for the isolation of bacteria removed from soils and morphological characteristics of strains cultivated in FAM medium with bromothymol blue as $\mathrm{pH}$ indicator.

\begin{tabular}{|c|c|c|c|c|c|}
\hline \multirow[t]{2}{*}{ Strains } & \multirow{2}{*}{$\begin{array}{l}\text { Exchangeable } \\
\text { potassium of } \\
\text { soils }\left(\mathrm{mg} \mathrm{dm}^{-3}\right)\end{array}$} & \multirow{2}{*}{$\begin{array}{l}\text { Culture medium } \\
\text { for isolation }\end{array}$} & \multicolumn{3}{|c|}{$\begin{array}{l}\text { Morphological characteristics } \\
\text { in FAM culture medium }\end{array}$} \\
\hline & & & $\mathrm{pH}$ & Color & EPS $^{(1)}$ \\
\hline \multicolumn{6}{|l|}{ Isolates in Alfenas MG Brazil } \\
\hline UNIFENAS 100-01 & 114 & $\mathrm{JNFb}$ & Acid & Yellow & Low \\
\hline UNIFENAS 100-16 & 30 & JMV & Acid & Yellow & Low \\
\hline UNIFENAS 100-21 & 30 & $\mathrm{JNFb}$ & Acid & Yellow & Low \\
\hline UNIFENAS 100-26 & 42 & $\mathrm{JNFb}$ & Alkaline & Yellowish & Low \\
\hline UNIFENAS 100-39 & 30 & $\mathrm{JNFb}$ & Acid & Yellow & Medium \\
\hline UNIFENAS 100-40 & 42 & $\mathrm{JNFb}$ & Acid/alkaline & Yellow & Low \\
\hline UNIFENAS 100-79 & 30 & LGI & Acid/alkaline & Yellow & High \\
\hline UNIFENAS 100-94 & 42 & JMV & Acid & Yellow & Low \\
\hline \multicolumn{6}{|c|}{ Isolates in Machado MG Brazil } \\
\hline UNIFENAS 100-13 & 128 & $\mathrm{JNFb}$ & Acid & Yellow & High \\
\hline UNIFENAS 100-27 & 120 & LGI & Acid & Yellow & Medium \\
\hline UNIFENAS 100-85 & 120 & LGI & Acid/alkaline & Yellowish & High \\
\hline UNIFENAS 100-93 & 68 & JMV & Acid/alkaline & Yellowish & High \\
\hline
\end{tabular}

(1) EPS production of exopolysaccharides.

Bacterial strains were cultivated in FAM culture medium (MAGALHÃES; DÖBEREINER, 1984) with bromothymol blue, till the emergence of isolated colonies. They were then transferred to liquid FAM medium for three days up to the growth $\log$ phase (with approximately $10^{9} \quad$ cells $\mathrm{mL}^{-}$ $\left.{ }^{1}\right)$.

Soil used in the assay was collected at $0-20 \mathrm{~cm}$ layer. It had the following chemical (SILVA, 2009) and granulometric (CAMARGO et al., 2009) characteristics: $\mathrm{pH}\left(\mathrm{CaCl}_{2}\right)=4.3$; P-Mehlich $=1.0 \mathrm{mg} \mathrm{dm}^{-3} ; \mathrm{K}=30 \mathrm{mg} \mathrm{dm}{ }^{-3} ; \mathrm{Ca}^{2+}=$ $0.4 \mathrm{cmol}_{\mathrm{c}} \mathrm{dm}^{-3} ; \mathrm{Mg}^{2+}=0.2 \mathrm{cmol}_{\mathrm{c}} \mathrm{dm}^{-3} ; \mathrm{Al}^{3+}=0.8$ $\mathrm{cmol}_{\mathrm{c}} \mathrm{dm}^{-3} ; \mathrm{H}+\mathrm{Al}=4.7 \mathrm{cmol}_{\mathrm{c}} \mathrm{dm}^{-3} ; \mathrm{SB}=0.7 \mathrm{cmol}_{\mathrm{c}}$ $\mathrm{dm}^{-3} ; \mathrm{CTC}=5.4 \mathrm{cmol}_{\mathrm{c}} \mathrm{dm}^{-3} ; \mathrm{V}=13 \% ; \mathrm{m}: 54 \%$; $\mathrm{MO}=18 \mathrm{~g} \mathrm{dm}^{-3}$ and P-rem $=32 \mathrm{mg} \mathrm{L}^{-1}$; sand $=812$ $\mathrm{g} \mathrm{kg}^{-1}$; silt $69 \mathrm{~g} \mathrm{~kg}^{-1}$ and clay $=119 \mathrm{~g} \mathrm{~kg}^{-1}$. Alternative $\mathrm{K}$ source employed was phonolite rock powder, finely ground and passed through a sieve with $0.25 \mathrm{~mm}$ mesh (60 mesh), with $8.0 \% \mathrm{~K}_{2} \mathrm{O}$, of which $1.2 \%$ soluble $\mathrm{K}_{2} \mathrm{O}$ in citric acid.

Assay comprised fifteen treatments: 12 treatments with phonolite and inoculation with bacterial strains; three control treatments: a control treatment (without phonolite and without inoculation); one treatment with phonolite without inoculation; one treatment with $\mathrm{KCl}$ alone. Design was totally randomized, with four replications. 
Further, $0.25 \mathrm{dm}^{3}$ soil lots were weighed and transferred to $0.3 \mathrm{dm}^{3}$ plastic containers. Phonolite and $\mathrm{KCl}$ dose was applied to provide the soil with $195 \mathrm{mg} \mathrm{dm}^{-3} \mathrm{~K}$. Phonolite was mixed with a volume of soil from each recipient. $\mathrm{KCl}$ was applied by the solution. Further, $3 \mathrm{~mL}$ of bacterial suspension was used on the soil surface of each recipient in inoculated treatments. Assay was performed during 90 days, with humidity at about $70 \%$ by periodic weighing of flasks. Distilled water replaced water lost through evaporation. Flasks were maintained in lab conditions, at room temperature.

At the end of the incubation, soil lots were removed from the flasks, air-dried and a sample was retrieved from each flask to determine $\mathrm{K}^{+}$rates, extracted by Mehlich and resin methods. They were quantified by flame photometry; potential acidity ( $\mathrm{H}+\mathrm{Al}) ; \mathrm{pH}$ in $\mathrm{CaCl}_{2}$ (RAIJ et al., 2001; SILVA, 2009).
Solubility efficiency was calculated according to results obtained from resin extracting solution, according to the formula:

$$
E S=\left[\frac{K \text { soluble treatment }}{K \mathrm{KCl}}\right] \times 100
$$

where:

$\mathrm{ES}=$ efficiency of solubility;

$\mathrm{K}$ soluble treatment $=$ rate of $\mathrm{K}$ extracted by resin;

$\mathrm{K} \mathrm{KCl}=$ rate of $\mathrm{K}$ in treatment soil with

$\mathrm{KCl}$

Data underwent analysis of variance and means of the four replications were compared by Scott-Knott test at $5 \%$ probability, with Sisvar (FERREIRA, 2011).

$\mathrm{K}^{+}$rates were quantified by extraction methods, Melich $(\mathrm{Km})$ and Resin $(\mathrm{Kr})$. Table 2 provides final $\mathrm{pH}$ and potential acidity $(\mathrm{H}+\mathrm{Al})$ rates in the soil.

Table 2. Rates of residual $\mathrm{K}^{+}$, evaluated by Mehlich method $(\mathrm{Km})$ and by resin $(\mathrm{Kr})$; efficiency of solubility (ES), $\mathrm{pH}$ and potential acidity $(\mathrm{H}+\mathrm{Al})$ of soil samples.

\begin{tabular}{cccccc}
\hline \multirow{2}{*}{ Treatments } & $\mathrm{Km}$ & $\mathrm{Kr}$ & \multirow{2}{*}{$\begin{array}{c}\mathrm{ES}(\%) \\
(\mathrm{Kr})\end{array}$} & $\begin{array}{c}\mathrm{pH} \\
\left(\mathrm{CaCl}_{2}\right)\end{array}$ & $\begin{array}{c}\mathrm{H}+\mathrm{Al} \\
\left(\mathrm{cmol}_{\mathrm{c}} \mathrm{dm}^{-3}\right)\end{array}$ \\
\cline { 2 - 3 } Soil with phonolite and inoculation with bacterial strains & & & & \\
\hline UNIFENAS 100-01 & $89 \mathrm{~b}$ & $86 \mathrm{~b}$ & $28 \mathrm{~b}$ & $5.0 \mathrm{a}$ & $1.9 \mathrm{c}$ \\
UNIFENAS 100-13 & $83 \mathrm{~b}$ & $78 \mathrm{c}$ & $25 \mathrm{c}$ & $4.8 \mathrm{~b}$ & $3.0 \mathrm{a}$ \\
UNIFENAS 100-16 & $90 \mathrm{~b}$ & $84 \mathrm{~b}$ & $28 \mathrm{~b}$ & $4.9 \mathrm{~b}$ & $1.6 \mathrm{c}$ \\
UNIFENAS 100-21 & $82 \mathrm{~b}$ & $78 \mathrm{c}$ & $26 \mathrm{c}$ & $4.6 \mathrm{c}$ & $1.7 \mathrm{c}$ \\
UNIFENAS 100-26 & $67 \mathrm{c}$ & $66 \mathrm{~d}$ & $21 \mathrm{~d}$ & $5.1 \mathrm{a}$ & $1.9 \mathrm{c}$ \\
UNIFENAS 100-27 & $85 \mathrm{~b}$ & $83 \mathrm{~b}$ & $27 \mathrm{~b}$ & $4.8 \mathrm{~b}$ & $1.8 \mathrm{c}$ \\
UNIFENAS 100-39 & $90 \mathrm{~b}$ & $89 \mathrm{~b}$ & $29 \mathrm{~b}$ & $4.8 \mathrm{~b}$ & $2.0 \mathrm{c}$ \\
UNIFENAS 100-40 & $84 \mathrm{~b}$ & $77 \mathrm{c}$ & $25 \mathrm{c}$ & $4.9 \mathrm{~b}$ & $2.4 \mathrm{c}$ \\
UNIFENAS 100-79 & $84 \mathrm{~b}$ & $80 \mathrm{c}$ & $26 \mathrm{c}$ & $5.0 \mathrm{a}$ & $1.6 \mathrm{c}$ \\
UNIFENAS 100-85 & $69 \mathrm{c}$ & $66 \mathrm{~d}$ & $22 \mathrm{~d}$ & $5.1 \mathrm{a}$ & $1.9 \mathrm{c}$ \\
UNIFENAS 100-93 & $89 \mathrm{~b}$ & $87 \mathrm{~b}$ & $29 \mathrm{~b}$ & $5.1 \mathrm{a}$ & $1.6 \mathrm{c}$ \\
UNIFENAS 100-94 & $81 \mathrm{~b}$ & $77 \mathrm{c}$ & $25 \mathrm{c}$ & $4.8 \mathrm{c}$ & $1.7 \mathrm{c}$ \\
\hline Control treatments & & & & \\
\hline Soil with phonolite without inoculation & $64 \mathrm{c}$ & $61 \mathrm{~d}$ & $19 \mathrm{~d}$ & $4.5 \mathrm{c}$ & $3.4 \mathrm{a}$ \\
Soil without phonolite and inoculation & $27 \mathrm{~d}$ & $24 \mathrm{e}$ & $7 \mathrm{e}$ & $4.7 \mathrm{c}$ & $2.1 \mathrm{c}$ \\
Soil with KCl without inoculation & $293 \mathrm{a}$ & $298 \mathrm{a}$ & $99 \mathrm{a}$ & $4.6 \mathrm{c}$ & $2.5 \mathrm{~b}$ \\
\hline
\end{tabular}

Means followed by same letter did not differ by Scott-Knott test at $5 \%$ probability.

Highest $\mathrm{K}^{+}$rates in the soil, extracted by Mehlich extractor and by resin, occurred in treatment with $\mathrm{KCl}$. K was 5.5 times greater than that in treatment with phonolite without inoculation, and 10.8 times than that in treatment without $\mathrm{K}$. This result is due to the fact that $\mathrm{KCl}$ is highly soluble in water. Similar results with regard to $\mathrm{KCl}$ were obtained by Duarte, Pereira and Korndörfer (2013). It is actually an undesirable characteristic from the environmental point of view since losses through leaching increase and may cause eutrophication of water courses and underwater waters (LEONARDOS; THEODORO; ASSAD, 2000). 
There was a 2.4 times increase in $\mathrm{K}^{+}$rates in the treatment with phonolite when compared to control with no potassium fertilizer. Increase in $\mathrm{K}^{+}$ rates in the soil through the application of phonolite was also obtained by Teixeira et al (2012) and by Martins et al. (2015b). It has also been observed that phonolite associated with bacterial strain inoculation provided a three-fold increase in $\mathrm{K}^{+}$rates in the soil. The latter were similar to treatment with phonolite without inoculation only in treatments inoculated by strains 100-26 and 100-85.

In their in vitro study, Florentino et al. (2017) used the same bacterial strains and reported that bio-solubility provided $\mathrm{K}$ rates ranging between 4.0 and 12.5 times more when compared to treatment without inoculation. This fact showed the great potential of strains to increase $\mathrm{K}$ release from phonolite rocks and thus their feasibility in agriculture. $\mathrm{K}$ rates triggered by bacterial strains in the soil revealed a significantly reduced effect when compared to in vitro conditions (FLORENTINO et al., 2017). Consequently, there is a need for studies on soil bio-solubility to select the most efficient strains in the process.

Solubility efficiency (ES) may be underscored by strains UNIFENAS 100-01, UNIFENAS 100-16, UNIFENAS 100-27, UNIFENAS 100-39 and UNIFENAS 100-93, with an approximately increase of $28 \%$ of $\mathrm{K}^{+}$rate in the soil. According to Meena, Maurya and Verma (2014), soil microorganisms, including bacteria and fungi, have an important role in the solubility of non-available $\mathrm{K}^{+}$inorganic forms, with an increase in availability to plants.

Further, $\mathrm{pH}$ rates in $\mathrm{CaCl}_{2}$ ranged between 4.1 and 5.1. There was an increase in $\mathrm{pH}$ of the soil in treatments inoculated with all bacterial strains, except strains UNIFENAS 100-21 and UNIFENAS 100-94, when compared to control. Results differ from in vitro bio-solubility assays which correlate $\mathrm{pH}$ decrease of culture medium with the production of organic acids and with greater efficiency in the process of bio-solubility (SHENG et al., 2008).

However, in spite of the great capacity of bacterial strains in in vitro conditions shown above (FLORENTINO et al., 2017), it may be verified that different behaviors occur in the soil with regard to the efficiency in $\mathrm{K}$ solubility and in $\mathrm{pH}$ rates. Therefore, in-depth knowledge is required on microbial ecology and population dynamics in the soil (RICHARDSON, 2001).

Increase in $\mathrm{pH}$ and decrease in the soil's potential acidity $(\mathrm{H}+\mathrm{Al})$ through the application of phonolite may be due to calcium carbonate and magnesium in the phonolite (MARTINS et al., $2015 b)$. These authors showed increase in $\mathrm{pH}$ in the soil when rock powder was applied. According to Lapido-Loureiro, Melamed and Figueiredo Neto (2009), increase of $\mathrm{pH}$ in the soil is one of the assets of rock powder, besides low costs and slow release in the soil, avoiding losses by leaching. Increase in the soil's pH occurred mainly in treatments with inoculation, which may be associated to a greater release of carbonates from the rock triggered by bacterial strains.

Lapido-Loureiro and Nascimento (2009) underscore that, due to the mineral characteristics of the rocks, the $\mathrm{K}^{+}$in the rock powder has low solubility, or rather, slower than by conventional fertilizers even though they provide other macro and micro nutrients in their composition. Consequently, they have favorable traits for $\mathrm{pH}$ rise in the soil.

The use of phonolite plus inoculation of diazotrophic strains contributed towards a greater availability of potassium in the soil. Among the tested strains, strains UNIFENAS 100-01, UNIFENAS 100-16, UNIFENAS 100-27, UNIFENAS 100-39 and UNIFENAS 100-93 may be underscored. They were more efficient in the solubilization of the phonolites $\mathrm{K}^{+}$.

In spite of these results, $\mathrm{K}$ rates released by bacterial strains in the soil were low when compared to those in in vitro conditions. Further studies on bio-solubility in the soil are required to select the most efficient strains for the process.

\section{ACKNOWLEDGMENTS}

The author thank the Coordination for the Improvement of Higher Education Personnel (CAPES) for the PROSUP scholarship.

RESUMO: O objetivo desse estudo foi avaliar se a inoculação com estirpes de bactérias diazotróficas de comprovada capacidade de solubilizar potássio $(\mathrm{K})$ in vitro, contribui para a liberação de $\mathrm{K}$ no solo, após adubação com o pó da rocha fonolito. $\mathrm{O}$ experimento foi conduzido em recipientes contendo $0,3 \mathrm{dm}^{-3} \mathrm{de}$ solo contendo baixo teor de potássio. Foram utilizados 15 tratamentos, sendo: 12 com fonolito inoculados com as estirpes bacterianas e 3 tratamentos controle, um sem fonolito e sem inoculação, um contendo fonolito sem inoculação e um contendo $\mathrm{KCl}$, fertilizante solúvel, sem inoculação. Nos tratamentos contendo fonolito e $\mathrm{KCl}$, foi aplicada doses desses materiais para fornecer ao solo $195 \mathrm{mg} \mathrm{dm}^{-3} \mathrm{de} \mathrm{K}$. Foi utilizado delineamento 
inteiramente casualizado com quatro repetições. O solo foi incubado por 90 dias, em temperatura ambiente e a umidade foi mantida a cerca de $70 \%$ da capacidade de retenção. Após esse período, foram avaliados o teor de $\mathrm{K}^{+}$(Mehlich e resina), valor de $\mathrm{pH}$ e da acidez potencial (H+Al). A utilização do fonolito, associado a inoculação com a maioria das estirpes bacterianas contribuiu para aumentar a disponibilidade de potássio no solo, o valor de $\mathrm{pH}$ e reduzir a acidez potencial. Dentre as estirpes testadas, destacaram-se UNIFENAS 100-01, UNIFENAS 100-16, UNIFENAS 100-27, UNIFENAS 100-39 e UNIFENAS 100-93, que foram as mais eficientes para a solubilização do $\mathrm{K}^{+}$do fonolito. Apesar dos resultados observados, verificou-se que o teor de $\mathrm{K}$ liberado pelas estirpes bacterianas no solo foi reduzido quando comparado às condições in vitro, justificando assim, a necessidade de estudos de biossolubilização no solo visando selecionar as estirpes mais eficientes para desempenhar o processo.

PALAVRAS CHAVE: Fontes alternativas de potássio. Pó de rocha silicatada. Fatores limitantes de biossolubilização.

\section{REFERENCES}

ANDRADE, A. C.; FONSECA, D. M. da; GOMIDE, J. A.; VENEGAS, V. H. A.; MARTINS, C. E.; SOUZA, D. P. H. de. Produtividade e Valor Nutritivo do Capim-Elefante cv. Napier sob Doses Crescentes de Nitrogênio e Potássio. In: Revista Brasileira de Zootecnia, Viçosa, v. 29, n. 6, p. 1589-1595, 2000.

https://doi.org/10.1590/S1516-35982000000600001.

BRANDÃO, J. A. V.; LOPES-ASSAD, M. L. R.; CECCATO-ANTONINI, S. R. Solubilization of diabase and phonolite dust by filamentous fungus. Ceres, Viçosa, v. 61, n. 5, p. 740-745, 2014.

https://doi.org/10.1590/0034-737X201461050018.

CAMARGO, A. O.; MONIZ, A. C.; JORGE, J. A.; VALADARES, J. M. A. S. Métodos de análise química, mineralógica e física de solos do Instituto Agronômico de Campinas. Campinas/Instituto Agronômico. 77p. 2009. (Boletim Técnico 106, Edição revista e atualizada).

DNPM. Departamento Nacional de Produção Mineral. Sumário Mineral. Brasil: 2014. 141 p. Available at : < http://www.dnpm.gov.br/dnpm/paginas/sumario-mineral> ISSN 0101-2053.

DUARTE, I. N.; PEREIRA, H. S.; KORNDÖRFER, G. H. Lixiviação de potássio proveniente do termopotássio. Pesquisa Agropecuária Tropical, Goiânia, v. 43, n. 2, p. 195-200, 2013. https://doi.org/10.1590/S1983-40632013000200003.

FERREIRA, D. F. SISVAR: A computer statistical analysis system. Ciência e Agrotecnologia, Lavras, v. 35, n. 6, p. 1039-1042, 2011. https://doi.org/10.1590/S1413-70542011000600001.

FILGUEIRA, F. A. R. Novo manual de olericultura: agrotecnologia moderna na produção e comercialização de hortaliças. 3ª edição. Viçosa: UFV, 2008. 412 p. ISBN 9788572693134.

FLORENTINO, L. A.; REZENDE, A. V.; MIRANDA, C. C. M.; MESQUITA, A. C.; MANTOVANI, J. R.; BIANCHINI, H. C. Potassium solubilization in phonolite rock by diazotrophic bacteria. Comunicata Scientiae, Bom Jesus, v. 8, n. 1, p. 17-23, 2017. https://doi.org/10.14295/cs.v811.1292.

GIRGIS, M. G. Z.; KHALIL, H. M. A.; SHARAF, M. S. In Vitro evaluation of rock phosphate and potassium solubilizing potential of some Bacillus strains. Australian Journal of Basic and Applied Sciences, Jordan, v. 2, n. 1, p. 68-81, 2008. ISSN 1991-8178.

LAPIDO-LOUREIRO, F. E.; MELAMED, R.; FIGUEIREDO NETO, J. de (Ed.) Fertilizantes: agroindústria e sustentabilidade. Rio de Janeiro: CETEM/MCT, 2009. 645 p. ISBN 978-85-61121-47-1. 
LAPIDO-LOUREIRO, F. E.; NASCIMENTO, M. Importância e função dos fertilizantes numa agricultura sustentável e competitiva. In: LAPIDO-LOUREIRO, F. E.; MELAMED, R.; FIGUEIREDO NETO, J. de (Ed.) Fertilizantes: agroindústria e sustentabilidade. Rio de Janeiro: CETEM/MCT, p. 81-132, 2009. ISBN 857227-177-4.

LEONARDOS, O. H.; THEODORO, S. C. H.; ASSAD, M. L. Remineralization for sustainable agriculture: a tropical perspective from a Brazilian viewpoint. Nutrient Cycling in Agroecosystems, Dordrecht, v. 56, p. 39, 2000. https://doi.org/10.1023/A:1009855409700.

MAGALHÃES, F. M. M.; DÖBEREINER, J. Occurrence of Azospirillum amazonense in some Amazonian (Brazil) ecosystems. Revista de Microbiologia, São Paulo, v. 15, p. 246-252, 1984. ISSN 0001-3714.

MALAVOLTA, E. Manual de nutrição mineral de plantas. $1^{\text {a }}$ edição. São Paulo: Editora Agronômica Ceres, 2006. 631 p. ISBN 85-318-0047-1.

MANCUSO, M. A. C.; SORATTO, R. P.; COSTA, C. A.; CRUSCIOL, C. A. C.; CASTRO, G. S. A. Effect of potassium sources and rates on arabica coffee yield, nutrition, and macronutrient export. Revista Brasileira de Ciência do Solo, Viçosa, v.38, p.1448-1456, 2014. https://doi.org/10.1590/S0100-06832014000500010.

MARTINS, V.; GONÇALVES, A. S. F.; MARCHI, G.; GUILHERME, L. R. G.; MARTINS, E. de S. Solubilização de potássio em misturas de verdete e calcário tratadas termoquimicamente. Pesquisa Agropecuária Tropical, Goiânia, v. 45, n. 1, p. 66-72, 2015a. https://doi.org/10.1590/1983$40632015 \mathrm{v} 4527917$.

MARTINS, V.; SILVA, D. R. G.; MARCHI, G.; LEITE, M. C. A.; MARTINS, E. S.; GONÇALVES, A. S. F.; GUIMARÃES, L. R. Effect of alternative multinutrient sources on soil chemical properties. Revista Brasileira de Ciência do Solo, Viçosa, v. 39, p. 194-204, 2015b. https://doi.org/10.1590/01000683rbcs20150587.

MEENA, V. S., MAURYA, B. R., VERMA, J. P. Does a rhizospheric microorganism enhance $\mathrm{K}^{+}$availability in agricultural soils? Microbiological Research, Brussels, v. 169, 337-347, 2014.

https://doi.org/10.1016/j.micres.2013.09.003.

RAIJ, B. V.; ANDRADE, J. C.; CANTARELLA, H.; QUAGGIO, J. A. Análise química para avaliação da fertilidade de solos tropicais. Campinas: Instituto Agronômico, 2001. 285p. ISBN 85-85564-05-9.

RICHARDSON, A. E. Prospects for using soil microorganisms to improve the acquisition of phosphorus by plants. Australian Journal of Plant Physiology, Collingwood, v. 28, n. 9, p. 897-906, 2001. https://doi.org/10.1071/PP01093.

SANTOS, W. O.; MATIELLO, E. M.; DA COSTA, L. M.; ABRAHÃO, W. A. P. Characterization of verdete rock as a potential source of potassium. Ceres, Viçosa, v. 62, n. 4, p. 392-400, 2015.

https://doi.org/10.1590/0034-737X201562040009.

SILVA, F. C. Manual de análises químicas de solos, plantas e fertilizantes. 2. ed. rev. atual. Brasília/ Embrapa Informação Tecnológica. 2009, 627 p. ISBN 978-85-7383-430-7.

SHENG, X. F.; ZHAO, F.; HE, L. Y.; QIU, G.; CHEN, L. Isolation and characterization of silicate mineralsolubilizing Bacillus globisporus Q12 from the surfaces of weathered feldspar. Canadian Journal of Microbiology, Ottawa, v. 54, n. 12, p. 1064-1068, 2008. https://doi.org/10.1139/W08-089.

TEIXEIRA, A. M. S.; SAMPAIO, J. A.; GARRIDO, F. M. S.; MEDEIROS, M. E. Avaliação da rocha fonolito como fertilizante alternativo de potássio. Holos, Natal, v. 5, p. 21-33, 2012.

https://doi.org/10.15628/holos.2012.1102. 